\title{
EFFECT OF HYDRO-ALCOHOL SOLVENT POLARITY ON THE ANTIOXIDANT, ANTIBACTERIAL AND ANTI-INFLAMMATORY ACTIVITIES OF FOUR MOROCCAN LETTUCE VARIETIES (Lactuca sativa L.): A COMPARATIVE STUDY
}

\begin{abstract}
Badr Zekkori' ${ }^{1}$, Amar Bentayeb ${ }^{1}$, Abdelaziz Ed-Dra ${ }^{2}$, Fouzia Rhazi Filali ${ }^{2}$, Aissam Sbai ${ }^{1}$, Nisrine Chlif ${ }^{1}$, Mohamed EI Omari ${ }^{1}$ and Farid Khallouki ${ }^{3 凶}$

${ }^{1}$ Department of Chemistry, Team of Physical-Chemistry of Condensed Matter, Moulay Ismail University,

${ }^{2}$ Team of Microbiology and Health, Laboratory of Chemistry-Biology Applied to the Environment, Moulay Ismail University Faculty of Sciences, BP. 11201 Zitoune Meknes, Morocco

${ }^{3}$ Team of Ethnopharmacology and Pharmacognosy, Faculty of Sciences and Techniques Errachidia, Moulay Ismail University, BP 509, Boutalamine, Errachidia, Morocco $\otimes_{\text {farid_khallouki@yahoo.fr }}$

https://doi.org/10.34302/crpjfst/2021.13.4.11

\begin{tabular}{|c|c|}
\hline $\begin{array}{l}\text { Article history: } \\
\text { Received: } \\
8 \text { August } 2021 \\
\text { Accepted: } \\
24 \text { August } 2021 \\
\end{array}$ & $\begin{array}{l}\text { This research work aimed to find a correlation between solvent polarity } \\
\text { on the extraction yield, on the content of polyphenols and flavonoids as } \\
\text { well as on the antioxidant, antibacterial and anti-inflammatory } \\
\text { potencies of two red and two green varieties of Lactuca sativa L. }\end{array}$ \\
\hline $\begin{array}{l}\text { Keywords: } \\
\text { Lactuca sativa L; } \\
\text { Solvent polarity; } \\
\text { Antioxidant activity; } \\
\text { Antibacterial activity; } \\
\text { Anti-inflammatory activity. }\end{array}$ & $\begin{array}{l}\text { hydroalcoholic extracts. } \\
\text { The results showed that extraction with polar solvent }\left(\mathrm{H}_{2} \mathrm{O}, 100 \%\right) \\
\text { presented maximal yields while the alcohol alone gave the lowest } \\
\text { yields. Furthermore, the mixture between these two solvents with } \\
\text { different proportions (alcohol with water) showed more other } \\
\text { interesting characters than alcohol or water taken separately. } \\
\text { Phytochemical contents were affected by varying solvent polarity, } \\
\text { within, the extraction with solvent polarity } 5.8\left(\mathrm{H}_{2} \mathrm{O} 25 \% \text { /Ethanol }\right. \\
75 \% \text { ) showed the highest content of total polyphenols while the polarity } \\
\left.\text { of } 7.3 \text { ( } \mathrm{H}_{2} \mathrm{O} 50 \% \text { / Ethanol } 50 \%\right) \text {, was specifically richer in flavonoids. } \\
\text { Our results further showed that the extracts of the two red varieties } \\
\text { (capitata L nidus tenerrima and crispa) exhibited a broad spectrum of } \\
\text { bioactivities more significantly than the two green varieties (longifolia } \\
\text { and capitate L nidus jaggeri). The hydro-alcoholic extracts of polarity } \\
5.8 \text { were the most effective in vitro and in vivo in the evaluation of the } \\
\text { antioxidant, antibacterial and also anti-inflammatory capacities with the } \\
\text { best activity against DPPH was recorded for the red variety Lactuca } \\
\text { sativa var. crispa, moreover, this same extract at } 1 \text { mg / ml showed a } \\
\text { maximal inhibitory activity of } 80.8 \% \text { on the bovine serum albumin } \\
\text { denaturation, it showed also a comparable anti-inflammatory effect to } \\
\text { dexamethazone which is achieved at high concentrations ( } 2 \text { to } 4 \text { g / Kg). }\end{array}$ \\
\hline
\end{tabular}
\end{abstract}

\section{Introduction}

Lactuca sativa $\mathrm{L}$. is one of the most popular plant worldwide with an increased food consumption (Liu et al., 2007). According to statistics of the United Nations Food and Agriculture Organization, the production of lettuce and chicory all over the world was about 
26,779,564 tons in 2016, of which China alone being the major producer of about 14,933,121 tons annually.

Botanically, Lactuca sativa L. belongs to the family of Asteraceae, its leaves are endowed with minerals element, such as calcium, iron, potassium, magnesium, manganese, copper and zinc (Pirvulescu and Sala, 2013), in addition, it is considered as an excellent origin of phytonutrients that may impact positively human nutrition and Metabolism (López et al., 2014; Pinto et al., 2015). Nonetheless, lettuce is mentioned much less frequently for its medicinal properties (Harsha et al., 2013; Ahangarpour et al., 2014) even though previous studies carried out on its seeds have shown its potential health benefits against various conditions including its antimicrobial effects (Edziri et al., 2011), anxiolytics (Harsha and Anilakumar, 2013), antioxidants (Komaki et al., 2014), anti-inflammatory and analgesic effects as well (Soro et al., 2009; Harsha et al., 2013).

Generally, in Scientific literature, recommending the relative polarity of the solvent for an optimal depletion of plant material is somewhat scarse. According to some previous studies conducted respectively on the fruits of Quercus coccifera L and Juniperus phoenicea (El Akrem et al., 2007) as well as on aerial part of Limnophila aromatica (Quy et al., 2013), confirmed evidence that the yield and quality of the extracted metabolites are associated with solvent polarity and biological activities, indeed using a ternary mixture of solvents help improve the extraction yield and the content of polyphenols which affects bioactivities and the antioxidant potential more particularly.

In this study, we sought to compare the contents of polyphenols according to the quality of solvent depletion with increasing polarities of the leaves of four Moroccan varieties of Lactuca sativa and we will further evaluate their antimicrobial, antioxidant and antiinflammatory capacities.

\section{Materials and methods}

\subsection{Materials}

\subsubsection{Plant material}

In this experimental study, the vegetable products include the four lactuca sativa varieties: longifolia (Green variety), capitata $L$. nidus jaggeri (Green variety), capitata $L$ nidus tenerrima (Red variety) as well as crispa (Red variety). These were obtained from a farm located in Kenitra city in the Northwest of Morocco. After drying, the leaves were pulverized, and stored in food bag.

\subsubsection{Animals}

Male Wistar rats aged between 5 and 6 weeks and weighting 160-200g were obtained from the Emirate Center for wildlife propagation, in Misour, Morocco. The animals were allowed to adapt for a week, with water and food supplied ad libitum. The experimental animal Protocol approved by the Animal Ethical Committee, has been conducted in accordance with European legislation.

\subsection{Methods}

\subsubsection{Chemicals}

Ethanol was obtained from Fluka (Munich, Germany), Folin-Ciocalteu reagent and $\mathrm{NaNO}_{2}$ were obtained from MERCK (Darmstadt,Germany), Gallic acid, $\mathrm{Na}_{2} \mathrm{CO}_{3}$, $\mathrm{H}_{2} \mathrm{O}_{2}, \mathrm{NaOH}, \mathrm{AlCl}_{3}$ were obtained from Fisher scientific (Illkirch, France), Catechin, DPPH were obtained from Sigma-Aldrich (SaintLouis, USA), $\mathrm{K}_{3} \mathrm{Fe}(\mathrm{CN})_{6}$ was obtained from Farco chemical supplies (beijing, China), Trichloroacetic acid were obtained from LabChem (Chicago, USA), $\mathrm{FeCl}_{3}$ were obtained from SD fine-chem limited (Maharashtra, India), Ascorbic acid were purshased from Solvachim (Casablanca, Morocco), Formalin were obtained from Pure chems (Tamil Nadu, India).

\subsubsection{Preparation of extracts}

The solvent extraction was conducted with five solvents of different polarities reported in the Table 1. Soxhlet apparatus is used for continuous extraction until eachi of the solvent 
was discolored indicating extraction exhaustion. The extracts were designated as $\mathrm{EX}_{\mathrm{ij}}$ where $\mathrm{i}: 1$ to 4 for the four species studied and $\mathrm{j}: 1$ to 5 for the five solvent polarities.

Table 1. Water/Ethanol solvents (\% by weight) with their experimental and calculated polarities according to Snyder (1978) of the five extracts of each Lactuca sativa varieties and their respective designation

\begin{tabular}{|c|c|c|c|c|c|c|}
\hline \multicolumn{2}{|c|}{$\left(\mathrm{H}_{2} \mathrm{O} \%\right)$} & 100 & 75 & 50 & 25 & 0 \\
\hline \multicolumn{2}{|c|}{$(\mathrm{Et}-\mathrm{OH} \%)$} & 0 & 25 & 50 & 75 & 100 \\
\hline \multicolumn{2}{|c|}{ Polarity } & $10.2^{*}$ & 8.7 & 7.3 & 5.8 & $4.3^{*}$ \\
\hline \multirow{4}{*}{ 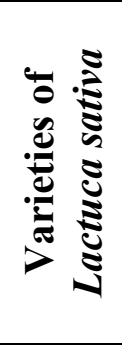 } & $\begin{array}{l}\text { Lactuca sativa L. var. } \\
\text { longifolia }\end{array}$ & $\mathrm{EX}_{11}$ & $\mathrm{EX}_{12}$ & $\mathrm{EX}_{13}$ & $\mathrm{EX}_{14}$ & $\mathrm{EX}_{15}$ \\
\hline & $\begin{array}{l}\text { Lactuca sativa L. var. capitata } \\
\text { L nidus jaggeri }\end{array}$ & $\mathrm{EX}_{21}$ & $\mathrm{EX}_{22}$ & $\mathrm{EX}_{23}$ & $\mathrm{EX}_{24}$ & $\mathrm{EX}_{25}$ \\
\hline & $\begin{array}{l}\text { Lactuca sativa L. var. capitata } \\
\text { L nidus tenerima }\end{array}$ & $\mathrm{EX}_{31}$ & $\mathrm{EX}_{32}$ & $\mathrm{EX}_{33}$ & $\mathrm{EX}_{34}$ & $\mathrm{EX}_{35}$ \\
\hline & Lactuca sativa L. var. crispa & $\mathrm{EX}_{41}$ & $\mathrm{EX}_{42}$ & $\mathrm{EX}_{43}$ & $\mathrm{EX}_{44}$ & $\mathrm{EX}_{45}$ \\
\hline
\end{tabular}

*: Snyder polarity (Snyder. L.R., 1978)

\subsubsection{Preliminary phytochemical screening}

To determine the class of secondary metabolites, present in the plant product, a qualitative phytochemical screening of Lactuca sativa L. species were carried out respectively for alkaloïds, flavonoïds, saponins, tannins, sterols as well as triterpenes following the exact protocol assayed by (Soro et al., 2016).

\subsubsection{Total phenol content (TPC)}

The TPC was determined using the protocol adapted by (Chekroun et al., 2015) with some modifications using the known Folin-Ciocalteu reagent. A volume of $100 \mu 1$ of extract or gallic acid as positive control were respectively added to $3 \mathrm{ml}$ of a $2 \% \mathrm{Na}_{2} \mathrm{CO}_{3}$ solution, and incubated for $5 \mathrm{~min}$. $100 \mu \mathrm{l}$ of Folin-Ciocalteu reagent $(1 \mathrm{~N})$ was added to the mixture, the solution was left for $30 \mathrm{~min}$ at room temperature. After that, the absorbances were measured at $765 \mathrm{~nm}$ against blank solution. The results are expressed in terms of Gallic acid equivalent (mgGAE eq/mg of dry mass).

\subsubsection{Total flavonoids content (TFC)}

The TFC was carried out according to the protocol of Chekroun et al. (2015). Briefly, $0.5 \mathrm{ml}$ of extract or cathechin at concentration $1 \mathrm{mg} / \mathrm{ml}$ were diluted in $2 \mathrm{ml}$ of distilled water.
$0.15 \mathrm{ml}$ of a $15 \%$ Sodium nitrite $\left(\mathrm{NaNO}_{2}\right)$ was added to the mixture, and incubated for $6 \mathrm{~min}$. $0.15 \mathrm{ml}$ of $\mathrm{AlCl}_{3}(10 \%), 2 \mathrm{ml}$ of $\mathrm{NaOH}(4 \%)$ and distilled water were added to bring the final volume to $5 \mathrm{ml}$. after $15 \mathrm{~min}$ of incubation the absorbance was measured at $510 \mathrm{~nm}$ and the TFC are expressed as $\mathrm{mg}$ of catechin equivalent (mg CAE/g dry mass).

\subsubsection{Antioxidant activity}

\subsubsection{FRAP (ferric-reducing antioxidant} power) radical scavenging activity

FRAP assay was tested according to the following method. $1 \mathrm{ml}$ of each extract solution at different concentrations (2 - $1-0.5-0.25-0.13$ $-0.06 \mathrm{mg} / \mathrm{ml}$ ) received $2.5 \mathrm{ml}$ of phosphate buffer $(0.2 \mathrm{~mol} / 1, \mathrm{pH} 6.6)$ and $2.5 \mathrm{ml}$ of a $1 \%$ potassium hexacyanoferrate $\left(\mathrm{K}_{3} \mathrm{Fe}(\mathrm{CN})_{6}\right)$ were added. The solution was incubated for $20 \mathrm{~min}$ at $50{ }^{\circ} \mathrm{C}$. After that, $2.5 \mathrm{ml}$ of trichloroacetic acid $\left(\mathrm{C}_{2} \mathrm{HCl}_{3} \mathrm{O}_{2}\right)(10 \%)$ were added to this solution which was centrifuged at $3,000 \mathrm{r} / \mathrm{min}$ for $10 \mathrm{~min}$, then $2.5 \mathrm{ml}$ of the supernatant were diluted into $2.5 \mathrm{ml}$ of distilled water. Finally, $0.5 \mathrm{ml}$ of a $0.1 \%$ iron trichloride was added to the mixture (Chekroun et al., 2015). 
2.2.6.2. 1.1-Diphenyl-2picrylhydrazine (DPPH) free radical scavenging activity

This was assayed exactly as described by (Harsha et al., 2013), $50 \mu 1$ of the sample extract at 5 concentrations (2.5 $-1.25-0.63-0.31-0.16$ $\mathrm{mg} / \mathrm{ml}$ ) were added to $2 \mathrm{ml}$ of phosphate buffer $(0.02 \mathrm{M}, \mathrm{pH} 6)$ and $1 \mathrm{~mL}$ of DPPH $(0.2 \mathrm{mM})$ $\left(\mathrm{C}_{18} \mathrm{H}_{13} \mathrm{~N}_{5} \mathrm{O}_{6}\right)$ and left for $30 \mathrm{~min}$ at room temperature in the dark. Afterwards, the absorbance was measured at $517 \mathrm{~nm}$ and activity was expressed as percentage of radical inhibition, the $\mathrm{IC}_{50}$ values were determined using XLSTAT 2016 software.

2.2.6.3. Determination of the scavenging effect on hydrogen peroxide

This was performed by the method of (Saumya and Mahaboob, 2011), briefly, a solution of hydrogen peroxide $\left(\mathrm{H}_{2} \mathrm{O}_{2}\right)$ $(20 \mathrm{mmol} / 1)$ was introduced in phosphate buffered saline (PBS, $0.1 \mathrm{~mol} / 1, \mathrm{pH}$ 7.4). A volume of $1 \mathrm{ml}$ of extracts or standard at concentration $(1 \mathrm{mg} / \mathrm{ml})$ were added to $0.6 \mathrm{ml}$ of hydrogen peroxide solution in PBS and incubated for $10 \mathrm{~min}$. The absorbance was measured at $230 \mathrm{~nm}$ against a blank solution.

$$
\text { H2O2 activity }(\%)=\frac{\operatorname{Abs}(1)-\operatorname{Abs}(2)}{\operatorname{Abs}(1)} * 100
$$

Where: Abs (1): Absorbance of the control and Abs (2): Absorbance of the extracts/standard.

\subsubsection{Evaluation of antibacterial activity}

The extracts were tested against Staphylococcus aureus (Gram +$)$ and Pseudomonas aeruginosa (Gram-) bacteria. These bacteria were obtained from the Mohammed V Regional Hospital of Meknes city (Morocco). The in vitro antibacterial activity of the scrutinized extracts was assessed as was described by (Smania and Delle, 2006; Balouiri et al., 2016) using the micro-dilution method and the minimum inhibitory concentration (MIC) were determined. Bacteria inoculation were prepared and adjusted to $0.5 \mathrm{McF}$ arland standard of turbidity, the extracts were at first prepared at the highest concentration and then serial twofold dilutions were performed (250,
$125,62.5,31.3,15.6,7.8,3.9,1.9$ and $1 \mathrm{mg} / \mathrm{mL}$ ). 96 well-sterile micro-plates were prepared by dispensing into each well $50 \mu \mathrm{L}$ of the diluted crude extract. These dilutions were inoculated with $50 \mu \mathrm{L}$ of a solution containing $10^{6} \mathrm{CFU} / \mathrm{mL}$ and $160 \mu \mathrm{L}$ of Mueller-Hinton Broth. In addition, a series of dilution containing Mueller Hinton broth and the tested inoculums was used as positive control; while another series of dilution containing only Mueller Hinton, broth was used as negative control.

The micro-plate was incubated at $35-37{ }^{\circ} \mathrm{C}$ for $24 \mathrm{~h}$. The MIC was considered the lowest concentration of the extract that inhibited the growth of $90 \%$ of the microorganism being tested as detected by lack of visual turbidity, matching a negative control. However, the minimum bactericidal concentration (MBC) is the lowest concentration of extract able to kill more than $99.9 \%$ of initial microbial inoculum.

\subsubsection{Inhibition of protein denaturation}

Inhibition of protein denaturation was evaluated by the method of Brindha and Arun (2014). briefly, the test solution $(600 \mu \mathrm{L})$ consisted of $500 \mu \mathrm{L}$ of $1 \%$ bovine serum albumin and $100 \mu \mathrm{L}(1 \mathrm{mg} / \mathrm{mL})$ of each plant extract. The mixture was kept at room temperature for 10 minutes, followed by heating at $51{ }^{\circ} \mathrm{C}$ for 20 minutes. The resulting solution was cooled to room temperature and the absorbance was recorded at $660 \mathrm{~nm}$. Acetyl salicylic acid was taken as a positive control. The experiment was conducted in triplicate and percent inhibition for protein denaturation was calculated using equation 2:

$$
\% \text { Inhibition }=100-\frac{A 1-A 2}{A 0} .100
$$

Where: A1: the absorbance of the sample, A2: the absorbance of the product control, A0: the absorbance of the positive control

\subsubsection{In-vivo antioxidant activity}

The rats, distributed into 3 groups of 5 animals, were treated by gavage for seven days. The distribution of animals was performed 
randomly as follows: the negative control group received only $1 \mathrm{~mL}$ of physiological water and the second and third groups were respectively treated with $1 \mathrm{~mL}$ of extract of Lactuca sativa $\mathrm{L}$. var crispa at the dose of $4 \mathrm{~g} / \mathrm{kg}$ as well as with 1 $\mathrm{mL}$ of ascorbic acid at the dose $10 \mathrm{mg} / \mathrm{g}$. After the treatment period, a blood sample was taken from each rat of the three batches and then centrifuged to recover the plasma (Soottawat et al., 2004). The antioxidant activity was then determined by using $100 \mu \mathrm{L}$ of plasma with the use of the aforementioned protocol (Harsha et al., 2013). The inhibition percentage was calculated using equation 3 :

$$
\mathrm{IP}=\frac{\operatorname{Abs}(1)-\operatorname{Abs}(2)}{\operatorname{Abs}(2)} * 100
$$

Where: Abs (1): Absorbance of treated group and Abs (2): Absorbance of the control group

\subsubsection{Formalin-induced chronic inflammation}

This was assayed as described by Al-Hejjaj et al. (2011), anti-inflammatory effect was evaluated by formalin-induced paw edema, within $0.1 \mathrm{ml}$ of $2 \%$ formalin injected into the sub-plantar area of the right hind paw of the ether anaesthetized rats. The extract was administered with doses of $800 \mathrm{mg} / \mathrm{kg}, 2 \mathrm{~g} / \mathrm{kg}$ and $4 \mathrm{mg} / \mathrm{kg}$ body weight for the batch treated with Lactuca sativa L. var crispa. The positive control group received a dose of $1 \mathrm{mg} / \mathrm{kg}$ of dexamethasone, while the negative control received only $2 \mathrm{~mL} / \mathrm{kg}$ of physiological water.
These treatments were given $30 \mathrm{~min}$ prior to formalin injection and continued for four consecutive days. All drugs were administered orally once daily using oral gavage.

\subsubsection{Statistical analysis}

The results are expressed as mean \pm standard deviation (SD) and analyzed by ANOVA test of three determination, a p-value $<0.05$ was considered statistically significant.

The heat maps were based on serval matrices containing different sets of information, Hierarchical Clustering Analysis (HCA) was carried out for columns using Euclidean distance. Circle scales were adopted for each individual case. Heat maps were created using the software (XLSTAT 2016, USA), based on their biological activities as was described by Darwish et al. (2018).

Principal component analysis (PCA), A multivariate analysis approach was used to reduce a large dataset of variables to a small dataset that still contains most of the information of the large dataset, the results were performed using XLSTAT 2016 software according to Saikat and Jun (2008).

\section{Results and discussions}

\subsection{Preliminary phytochemical test}

The four varieties of lettuce were found to contain tannins, flavonoids, anthocyanins, along with sterols through preliminary phytochemical screening, data are summarized in the Table 2.

Table 2. Phytochemical screening of the four varieties of Lactuca sativa L. studied

\begin{tabular}{|c|c|c|c|c|}
\hline \multirow{2}{*}{$\begin{array}{c}\text { Secondary } \\
\text { metabolism } \\
\text { families }\end{array}$} & \multicolumn{2}{|c|}{ GREEN VARIETIES } & \multicolumn{2}{|c|}{ RED VARIETIES } \\
\hline & longifolia & $\begin{array}{c}\text { capitata L nidus } \\
\text { jaggeri }\end{array}$ & $\begin{array}{c}\text { capitata } \mathrm{L} \\
\text { nidus tenerima }\end{array}$ & crispa \\
\hline Tanins & $\mathrm{P}$ & $\mathrm{P}$ & $\mathrm{P}$ & $\mathrm{P}$ \\
\hline Flavonoids & $\mathrm{P}$ & $\mathrm{P}$ & $\mathrm{P}$ & $\mathrm{P}$ \\
\hline Anthocyans & $\mathrm{P}$ & $\mathrm{P}$ & $\mathrm{P}$ & $\mathrm{P}$ \\
\hline $\begin{array}{l}\text { Sterols - } \\
\text { triterpens }\end{array}$ & $\mathrm{P}$ & $\mathrm{P}$ & $P$ & $\mathrm{P}$ \\
\hline Mucilage & $\mathrm{P}$ & $\mathrm{P}$ & $\mathrm{P}$ & $\mathrm{P}$ \\
\hline Alcaloïdes & A & A & A & $\mathrm{A}$ \\
\hline \multicolumn{4}{|c|}{ P : Presence } & A : Absence \\
\hline
\end{tabular}




\subsection{Yield of extraction}

The yield of extraction depends on solvent polarity, temperature, extraction time as well as lettuce variety of the sample. Under the same extraction time and temperature, solvent and sample chemical composition remain the most important parameters. In our study, extracts of the four varieties of Lactuca sativa L. were obtained by using different proportions of water and ethanol $\left(\mathrm{H}_{2} \mathrm{O} / \mathrm{EtOH}\right)$ as solvents of extraction.

Table 3. Solvent polarity on the extraction yields expressed as $\%$ of dry leaves powder of the four varieties Lactuca sativa L. For each solvent, values lacking a common letter are significantly different at $\mathrm{p}<0.05$ (Tukey's HSD test)

\begin{tabular}{|c|c|c|c|c|}
\hline \multirow{2}{*}{$\begin{array}{c}\text { SOLVENT } \\
\text { POLARITY }\end{array}$} & \multicolumn{2}{|c|}{ Green varieties } & \multicolumn{2}{c|}{ Red varieties } \\
\cline { 2 - 5 } & longifolia & $\begin{array}{c}\text { capitata } \mathrm{L} \text { nidus } \\
\text { jaggeri }\end{array}$ & $\begin{array}{c}\text { capitata } \mathrm{L} \\
\text { nidus tenerima }\end{array}$ & crispa \\
\hline 4.3 & $15.33 \pm 1.10^{\mathrm{E}}$ & $14.33 \pm 1.60^{\mathrm{E}}$ & $13.33 \pm 1.20^{\mathrm{E}}$ & $19.67 \pm 1.30^{\mathrm{DE}}$ \\
\hline 5.8 & $28.33 \pm 2.50^{\mathrm{CD}}$ & $26.67 \pm 2.60^{\mathrm{CD}}$ & $25.33 \pm 2.50^{\mathrm{CD}}$ & $29.00 \pm 3.00^{\mathrm{BC}}$ \\
\hline 7.3 & $34.67 \pm 3.70^{\mathrm{AB}}$ & $35.33 \pm 3.40^{\mathrm{ABC}}$ & $38.33 \pm 3.80^{\mathrm{AB}}$ & $41.33 \pm 4.30^{\mathrm{A}}$ \\
\hline 8.7 & $42.67 \pm 3.70^{\mathrm{AB}}$ & $36.67 \pm 3.70^{\mathrm{AB}}$ & $35.00 \pm 3.40^{\mathrm{ABC}}$ & $34.67 \pm 3.70^{\mathrm{AB}}$ \\
\hline 10.2 & $43.67 \pm 4.20^{\mathrm{A}}$ & $42.33 \pm 4.10^{\mathrm{A}}$ & $37.00 \pm 3.80^{\mathrm{AB}}$ & $38.67 \pm 4.00^{\mathrm{A}}$ \\
\hline
\end{tabular}

Our results are depicted in Table 3. Extraction yield increased with the increasing percentage of water giving rise of the respective solvent polarities $4.3,5.8,7.3,8.7$ and 10.2. Moreover, compared to other mixtures, the ethanolic extract showed low yields ranging from $\left(13.33 \pm 1.2^{\mathrm{E}} \%\right.$ to $\left.19.67 \pm 1.3^{\mathrm{DE}} \%\right)$ and the extracts of polarity 7.3 and 8.7 presented almost the same yield for the four varieties $\left(34.67 \pm 3.70^{\mathrm{AB}} \% \leq\right.$ yield $\left.\leq 42.67 \pm 3.70^{\mathrm{AB}} \%\right)$. On the other hand, aqueous extracts exhibited a higher yield ranging from $\left(37.00 \pm 3.80^{\mathrm{AB}} \%\right.$ to $43.67 \pm 4.20^{\mathrm{A}} \%$ ) due probably to highly glycosylated phenolics and other non-phenolic primary metabolites such as aminoacids, polypeptides and carbohydrates.

Table 4. Total polyphenol content (expressed as $\mathrm{mg}$ GAE/mg dry weight, means \pm standard deviation in function of the solvent polarity of the four varieties. For each solvent, values lacking a common

letter are significantly different at $\mathrm{p}<0.05$ (Tukey’s HSD test)

\begin{tabular}{|c|c|c|c|c|}
\hline \multirow{2}{*}{$\begin{array}{c}\text { SOLVENT } \\
\text { POLARITY }\end{array}$} & \multicolumn{2}{|c|}{ Green varieties } & \multicolumn{2}{c|}{ Red varieties } \\
\cline { 2 - 5 } & longifolia & $\begin{array}{c}\text { capitata } \mathrm{L} \text { nidus } \\
\text { jaggeri }\end{array}$ & $\begin{array}{c}\text { capitata } \mathrm{L} \\
\text { nidus tenerima }\end{array}$ & crispa \\
\hline 4.3 & $0.10 \pm 0.03^{\mathrm{FGH}}$ & $0.07 \pm 0.02^{\mathrm{GH}}$ & $0.17 \pm 0.02^{\mathrm{CDE}}$ & $0.28 \pm 0.03^{\mathrm{B}}$ \\
\hline 5.8 & $0.13 \pm 0.01^{\mathrm{EFG}}$ & $0.15 \pm 0.01^{\mathrm{DEF}}$ & $0.35 \pm 0.04^{\mathrm{A}}$ & $0.39 \pm 0.02^{\mathrm{A}}$ \\
\hline 7.3 & $0.09 \pm 0.01^{\mathrm{FGH}}$ & $0.11 \pm 0.01^{\mathrm{EFGH}}$ & $0.26 \pm 0.03^{\mathrm{B}}$ & $0.37 \pm 0.01^{\mathrm{A}}$ \\
\hline 8.7 & $0.09 \pm 0.01^{\mathrm{FGH}}$ & $0.10 \pm 0.01^{\mathrm{EFGH}}$ & $0.23 \pm 0.00^{\mathrm{BC}}$ & $0.22 \pm 0.03^{\mathrm{BCD}}$ \\
\hline 10.2 & $0.06 \pm 0.03^{\mathrm{H}}$ & $0.07 \pm 0.03^{\mathrm{GH}}$ & $0.24 \pm 0.01^{\mathrm{B}}$ & $0.15 \pm 0.04^{\mathrm{DEF}}$ \\
\hline
\end{tabular}

As regard of flavonoids chemical content, the obtained results revealed that the red varieties presented likewise the most important content of flavonoids mostly observable with solvents polarities of 7.3 and 8.7 respectively for crispa variety and at polarities 8.7 and 10.2 for nidis tenerrima variety. The results are presented in table 5 below.

\subsection{Total phenolic content}

Phenolic compounds in plants constitute one the major class of secondary plant metabolites with well-known bioactive potential attributed 
in great part to their antioxidant, antiradical and antibacterial activities.

The extraction of the phenolics is influenced by both the polarity of the solvents and the variety of Lactuca sativa $\mathrm{L}$ as well. The yields of phenolics from the two red varieties were significantly superiors compared to the 2 other green varieties, this data were in agreement with the finding reported by (Llorach et al., 2008) who have studied five Spain lettuce varieties.
We next observed that in the case of red varieties, the solvents polarities of 5.8 and 7.3 have significantly depleted more polyphenols content compared with the other ones, of these, the variety Lactuca sativa L. var. crispa had the most important polyphenols content. As regard of the green varieties, i.e. Lactuca sativa L. var. longifolia and Lactuca sativa L. var. capitata nidus jaggeri, they did show no significant difference in all extraction field Table 4.

Table 5. Total flavonoids content expressed as $\mathrm{mg}$ CAE/g dry weight, means \pm standard deviation according to the solvent polarity of the four varieties. For each solvent, values lacking a common letter are significantly different at $\mathrm{p}<0.05$ (Tukey's HSD test)

\begin{tabular}{|c|c|c|c|c|}
\hline \multirow{2}{*}{$\begin{array}{c}\text { SOLVENT } \\
\text { POLARITY }\end{array}$} & \multicolumn{2}{|c|}{ Green varieties } & \multicolumn{2}{c|}{ Red varieties } \\
\cline { 2 - 5 } & longifolia & $\begin{array}{c}\text { capitata } \mathrm{L} \text { nidus } \\
\text { jaggeri }\end{array}$ & $\begin{array}{c}\text { capitata } \mathrm{L} \\
\text { nidus tenerima }\end{array}$ & crispa \\
\hline 4.3 & $1.41 \pm 0.02^{\mathrm{O}}$ & $1.44 \pm 0.04^{\mathrm{O}}$ & $3.74 \pm 0.03^{\mathrm{G}}$ & $3.91 \pm 0.01^{\mathrm{G}}$ \\
\hline 5.8 & $2.58 \pm 0.16^{\mathrm{JK}}$ & $2.34 \pm 0.03^{\mathrm{L}}$ & $6.97 \pm 0.1^{\mathrm{D}}$ & $6.45 \pm 0.02^{\mathrm{E}}$ \\
\hline 7.3 & $2.71 \pm 0.01^{\mathrm{I}}$ & $2.98 \pm 0.03^{\mathrm{H}}$ & $9.59 \pm 0.01^{\mathrm{B}}$ & $10.27 \pm 0.02^{\mathrm{A}}$ \\
\hline 8.7 & $2.80 \pm 0.02^{\mathrm{HI}}$ & $2.41 \pm 0.16^{\mathrm{KL}}$ & $7.54 \pm 0.01^{\mathrm{C}}$ & $9.45 \pm 0.06^{\mathrm{B}}$ \\
\hline 10.2 & $1.66 \pm 0.04^{\mathrm{N}}$ & $2.12 \pm 0.01^{\mathrm{M}}$ & $7.45 \pm 0.07^{\mathrm{C}}$ & $5.87 \pm 0.1^{\mathrm{F}}$ \\
\hline
\end{tabular}
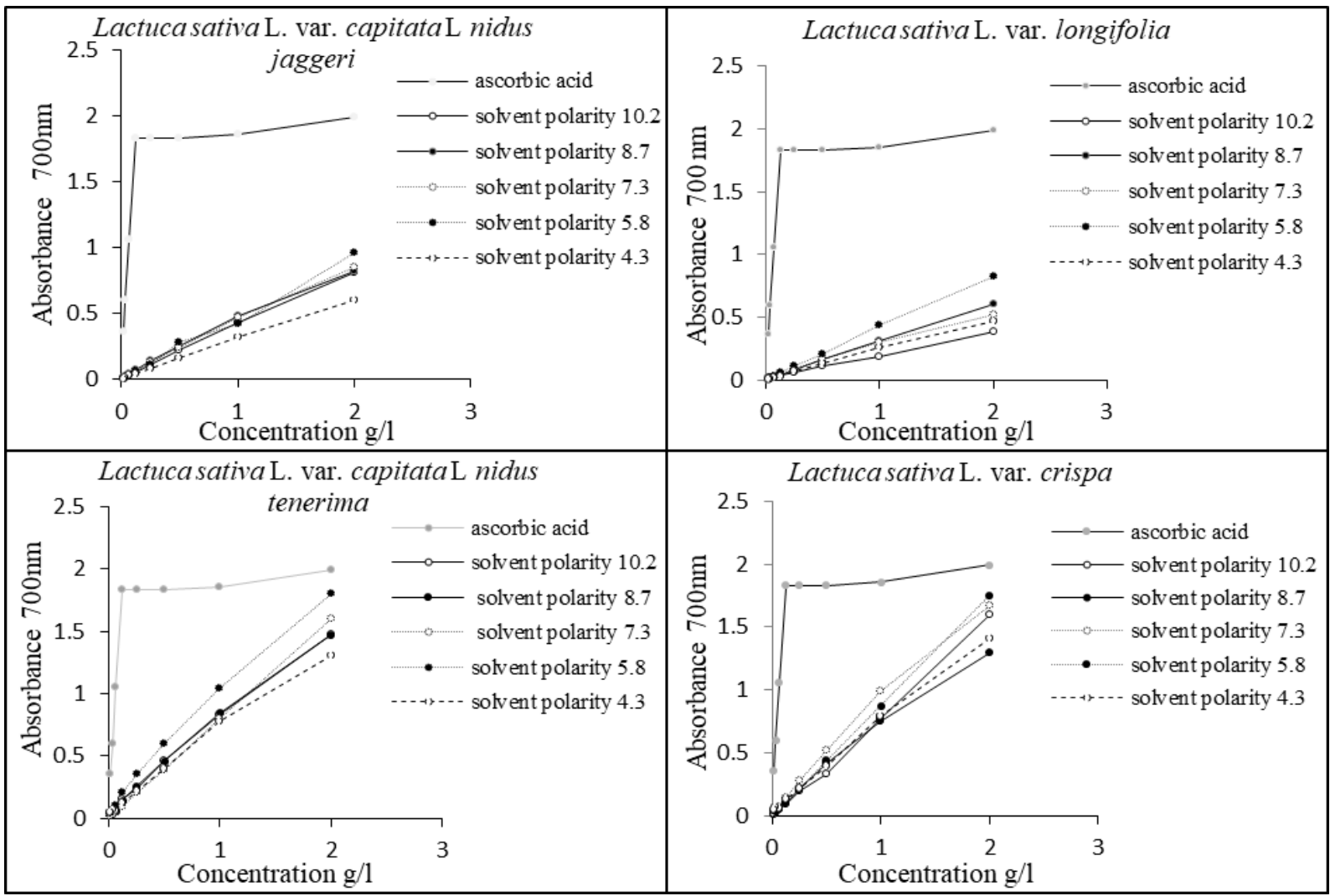

Figure 1. Reducing power of ascorbic acid and of Lactuca sativa L. extracts in different solvent polarities 
Furthermore, previous elegant reports have been reported about characterization of the individual polyphenolics in a variety of lettuce extracts, Llorash et al.(2008) reported that the lettuce is a species rich particularly in hydroxycinnamic acid such as the caffeic acid derivatives along with flavonol derivatives including quercetin and a flavone such as luteolin, Moreover in our recent study we also highlighted the presence of ferulic acid with a prenyl chain (GOFA) in Lactuca sativa var crispa species (Zekkori et al., 2018).

\subsection{Antioxidant activity}

\subsubsection{FRAP (ferric-reducing antioxidant} power) radical scavenging activity

The FRAP activity of Lactuca sativa L. of 20 extracts was investigated by following reduction $\mathrm{Fe}^{3+}$ to $\mathrm{Fe}^{2+}$. The results are depicted in the Figure. 1 and clearly showed that the red varieties exhibited an important reduction power compared to the green varieties. Moreover, at a concentration of $2 \mathrm{mg} / \mathrm{mL}$ they also clearly manifested an antioxidant activity comparable to the ascorbic acid. Moreover, all extracts showed a clear dose-response relationship. Also, the hydro-alcoholic extracts of polarity 5.8 present a significant reduction power compared to aqueous and ethanolic extracts.
3.4.2. DPPH free radical scavengingactivity

2-diphenyl-1-picrylhydrazyl (DPPH) is a radical able to take one electron or one hydrogen radical and next form a stable diamagnetic nonradical product, it changes its color from purple to yellow indicating an antioxidant potential of the sample solution. For this Assay, Ascorbic acid was used as a positive control $\left(\mathrm{IC}_{50}=0.03 \pm 0.00^{\mathrm{A}}\right)$. According to the results obtained, the activity of the four Lactuca sativa L. subspecies with their respective $\mathrm{IC}_{50}$ values $(\mathrm{mg} / \mathrm{mL})$ in different solvent polarities are depicted in Table 6.

The $\mathrm{IC}_{50}$ values were determined to help evaluate the content of the samples required for $50 \%$ inhibition of DPPH radicals. The extracts of Lactuca sativa L. var. crispa have shown the best free radical scavenger potency for respectively the solvents extracts polarities 10.2; $8.7 ; 5.8$ and 4.3 . the $\mathrm{IC}_{50}$ were ranged from $\left(1.7 \pm 0.8^{\mathrm{GHI}} \mathrm{mg} / \mathrm{mL}\right)$ for extract of polarity 5.8 to $\left(9.1 \pm 0.8^{\mathrm{D}} \mathrm{mg} / \mathrm{mL}\right)$ for extract of polarity 4.3 , furthermore, the extracts of Lactuca sativa L. var. capitata L nidus tenerima showed also an interesting result of bioactivity with an $\mathrm{IC}_{50}$ of $\left(1.2 \pm 0.7^{\mathrm{HI}} \mathrm{mg} / \mathrm{mL}\right)$ for the Extract of polarity 7.3 .

Table 6. $\mathrm{IC}_{50}$ values $(\mathrm{mg} / \mathrm{mL})$ of extracts of four varieties of Lactuca sativa $\mathrm{L}$. in different solvent polarities. For each solvent, values lacking a common letter are significantly different at $\mathrm{p}<0.05$

(Tukey's HSD test)

\begin{tabular}{|c|c|c|c|c|}
\hline \multirow{2}{*}{$\begin{array}{c}\text { SOLVENT } \\
\text { POLARITY }\end{array}$} & \multicolumn{2}{|c|}{ Green varieties } & \multicolumn{2}{c|}{ Red varieties } \\
\cline { 2 - 5 } & longifolia & $\begin{array}{c}\text { capitata } \mathrm{L} \text { nidus } \\
\text { jaggeri }\end{array}$ & $\begin{array}{c}\text { capitata } \mathrm{L} \\
\text { nidus tenerima }\end{array}$ & crispa \\
\hline 4.3 & $22.7 \pm 0.7^{\mathrm{B}}$ & $27.1 \pm 1.2^{\mathrm{A}}$ & $11.6 \pm 0.1^{\mathrm{C}}$ & $9.1 \pm 0.8^{\mathrm{D}}$ \\
\hline 5.8 & $4.1 \pm 1.0^{\mathrm{FG}}$ & $5.6 \pm 0.3^{\mathrm{EF}}$ & $1.9 \pm 0.4^{\mathrm{GHI}}$ & $1.7 \pm 0.8^{\mathrm{GHI}}$ \\
\hline 7.3 & $8.7 \pm 0.2^{\mathrm{D}}$ & $5.5 \pm 0.6^{\mathrm{EF}}$ & $1.2 \pm 0.7^{\mathrm{HI}}$ & $2.1 \pm 0.6^{\mathrm{GHI}}$ \\
\hline 8.7 & $6.4 \pm 0.1^{\mathrm{E}}$ & $5.3 \pm 0.4^{\mathrm{EF}}$ & $3.7 \pm 0.4^{\mathrm{FG}}$ & $2.3 \pm 0.9^{\mathrm{GHI}}$ \\
\hline 10.2 & $7.4 \pm 0.6^{\mathrm{DE}}$ & $7.0 \pm 0.3^{\mathrm{DE}}$ & $3.3 \pm 0.1^{\mathrm{FGH}}$ & $2.3 \pm 0.3^{\mathrm{GHI}}$ \\
\hline
\end{tabular}

The lower the $\mathrm{IC}_{50}$ value, the higher the antioxidant capacity of the sample extract Table 3. Lactuca sativa L. var. longifolia and Lactuca sativa L. var. capitata L nidus jaggeri varieties exhibited the greatest $\mathrm{IC}_{50}$ values, which means that they were less active at the antioxidant level.
Our results mirrored those already reported by (Gan and Azrina, 2016). 
3.4.3. Determination of the scavenging effect on hydrogen peroxide

As shown in Table 7, all the four varieties of lettuce showed a positive activity on the free radicals of hydrogen peroxide, in addition, the extracts of polarity 5.8 had the most significant activity followed by the extracts of polarity 7.3, 8.7 and the aqueous extract. In contrast, the ethanolic extract possesses the lowest activity of neutralization of the above-mentioned free radicals.

Table 7. Hydrogen peroxide scavenging activity in function of the extracts of different solvent polarities. For each solvent, values lacking a common letter are significantly different at $\mathrm{p}<0.05$

(Tukey's HSD test)

\begin{tabular}{|c|c|c|c|c|}
\hline \multirow{2}{*}{$\begin{array}{c}\text { SOLVENT } \\
\text { POLARITY }\end{array}$} & \multicolumn{2}{|c|}{ Green varieties } & \multicolumn{2}{c|}{ Red varieties } \\
\cline { 2 - 5 } & longifolia & $\begin{array}{c}\text { capitata } \mathrm{L} \text { nidus } \\
\text { jaggeri }\end{array}$ & $\begin{array}{c}\text { capitata } \mathrm{L} \\
\text { nidus tenerima }\end{array}$ & crispa \\
\hline 4.3 & $0.42 \pm 0.01^{\mathrm{I}}$ & $0.58 \pm 0.03^{\mathrm{G}}$ & $0.42 \pm 0.02^{\mathrm{I}}$ & $0.57 \pm 0.02^{\mathrm{G}}$ \\
\hline 5.8 & $0.59 \pm 0.01^{\mathrm{FG}}$ & $0.72 \pm 0.03^{\mathrm{D}}$ & $0.95 \pm 0.02^{\mathrm{A}}$ & $0.91 \pm 0.03^{\mathrm{B}}$ \\
\hline 7.3 & $0.46 \pm 0.01^{\mathrm{H}}$ & $0.70 \pm 0.02^{\mathrm{DE}}$ & $0.90 \pm 0.03^{\mathrm{B}}$ & $0.81 \pm 0.02^{\mathrm{C}}$ \\
\hline 8.7 & $0.46 \pm 0.01^{\mathrm{H}}$ & $0.67 \pm 0.03^{\mathrm{E}}$ & $0.67 \pm 0.01^{\mathrm{E}}$ & $0.73 \pm 0.03^{\mathrm{D}}$ \\
\hline 10.2 & $0.43 \pm 0.01^{\mathrm{HI}}$ & $0.62 \pm 0.01^{\mathrm{F}}$ & $0.60 \pm 0.02^{\mathrm{FG}}$ & $0.60 \pm 0.03^{\mathrm{FG}}$ \\
\hline
\end{tabular}

\subsection{Evaluation of antibacterial activity}

According to the preliminary phytochemical tests assayed, the hydroalcoholic extracts of Lactuca sativa subspecies were endowed with a significant content of polyphenols and flavonoids which influenced the antibacterial activity. This bioassay was evaluated by the method of microdilution and the results are summarized in Table 8 and revealed that the extracts of the four lettuce varieties tested against the Staphylococcus aureus strain presented a tolerance for 18 extracts from the 20 tested, however, a notable bacteriostatic effect was observed for the two extracts of polarities 4.3 and 5.8 of the plant Lactuca sativa L.var. capitata L.nidus jaggeri.
The aqueous extract, the extract of polarity 8.7 and the ethanolic extract of the plant Lactuca sativa L. var. capitata L. nidus tenerrima have showed the same MIC. Our results are confirmatory to those already reported by (Edziri et al. 2011).

As regards to the Pseudomonas aeruginosa strain Table 8B, this also showed a tolerance for the majority of the extracts with the exception being observable with Lactuca sativa $\mathrm{L}$. var. capitata L. nidus jaggeri variety where an evident bacteriostatic activity for the extracts of polarities respectively of $4.3,5.8,7.3$ and 8.7 have been demonstrated.

Table 8. Antibacterial activity of Lactuca sativa L. extracts against Staphylococcus aureus and Pseudomonas aeruginosa strains. If $\mathrm{MBC} / \mathrm{MIC}<2$, the extract presents a bactericidal effect, if $\mathrm{MBC} / \mathrm{MIC}>2$, the extract is bacteriostatic and if $\mathrm{MBC} / \mathrm{MIC}>32$, the bacterial strain presents a tolerance effect $(\mathrm{T}) * M I C * * M B C$ and $* * * M B C / M I C$.

\begin{tabular}{|c|c|c|c|c|}
\hline \multicolumn{5}{|c|}{ A: Lactuca sativa L. extracts against Staphylococcus aureus strain } \\
\hline $\begin{array}{c}\text { SOLVENT } \\
\text { POLARITY }\end{array}$ & $\begin{array}{c}\text { Lactuca sativa } \mathrm{L} . \\
\text { var. longifolia }\end{array}$ & $\begin{array}{c}\text { Lactuca } \text { sativa } \text { L. var. } \\
\text { capitata } \text { L nidus jaggeri }\end{array}$ & $\begin{array}{c}\text { Lactuca sativa } \mathrm{L} . \\
\text { var. capitata } \mathrm{L} \\
\text { nidus tenerima }\end{array}$ & $\begin{array}{c}\text { Lactuca sativa } \\
\text { L. var. crispa }\end{array}$ \\
\hline \multirow{3}{*}{4.3} & $7.0^{*}$ & 1.5 & 3.0 & 2.0 \\
& $-* *$ & 43.5 & - & - \\
\hline 5.8 & 9.0 & 29.0 & $\mathrm{~T}$ & $\mathrm{~T}$ \\
\hline
\end{tabular}




\begin{tabular}{|c|c|c|c|c|}
\hline & $\begin{array}{l}- \\
\mathrm{T}\end{array}$ & $\begin{array}{l}54.0 \\
27.0\end{array}$ & $\begin{array}{l}- \\
\mathrm{T}\end{array}$ & $\begin{array}{l}- \\
\mathrm{T}\end{array}$ \\
\hline \multirow{3}{*}{7.3} & 9.0 & 10.0 & 14.0 & 8.0 \\
\hline & - & - & - & - \\
\hline & $\mathrm{T}$ & $\mathrm{T}$ & $\mathrm{T}$ & $\mathrm{T}$ \\
\hline \multirow{3}{*}{8.7} & 1.0 & 9.5 & 3.0 & 6.0 \\
\hline & - & - & - & - \\
\hline & $\mathrm{T}$ & $\mathrm{T}$ & $\mathrm{T}$ & $\mathrm{T}$ \\
\hline \multirow{3}{*}{10.2} & 9.0 & 9.0 & 3.0 & 9.0 \\
\hline & - & - & - & - \\
\hline & $\mathrm{T}$ & $\mathrm{T}$ & $\mathrm{T}$ & $\mathrm{T}$ \\
\hline \multicolumn{5}{|c|}{ B : Lactuca sativa L. extracts against Pseudomonas aeruginosa strain } \\
\hline $\begin{array}{l}\text { SOLVENT } \\
\text { POLARITY }\end{array}$ & $\begin{array}{l}\text { Lactuca sativa L. } \\
\text { var. longifolia }\end{array}$ & $\begin{array}{l}\text { Lactuca sativa L. var. } \\
\text { capitata L nidus jaggeri }\end{array}$ & $\begin{array}{l}\text { Lactuca sativa L. } \\
\text { var. capitata } \mathrm{L} \\
\text { nidus tenerima }\end{array}$ & $\begin{array}{l}\text { Lactuca sativa } \\
\text { L. var. crispa }\end{array}$ \\
\hline \multirow{3}{*}{4.3} & $115.0 *$ & 8.0 & 3.0 & 10.0 \\
\hline & $119.0 * *$ & 43.5 & - & - \\
\hline & $1.6 * * *$ & 5.4 & $\mathrm{~T}$ & $\mathrm{~T}$ \\
\hline \multirow{3}{*}{5.8} & 140.0 & 10.0 & 11.0 & 1.0 \\
\hline & - & 54.0 & - & - \\
\hline & $\mathrm{T}$ & 5.4 & $\mathrm{~T}$ & $\mathrm{~T}$ \\
\hline \multirow{3}{*}{7.3} & - & 54.0 & 14.0 & 8.0 \\
\hline & - & 250.0 & - & - \\
\hline & $\mathrm{T}$ & 5.6 & $\mathrm{~T}$ & $\mathrm{~T}$ \\
\hline \multirow{3}{*}{8.7} & - & 49.0 & 13.0 & 250.0 \\
\hline & - & 250.0 & - & 250.0 \\
\hline & $\mathrm{T}$ & 5.1 & $\mathrm{~T}$ & 1.0 \\
\hline \multirow{3}{*}{10.2} & - & 48.0 & - & - \\
\hline & - & - & - & - \\
\hline & $\mathrm{T}$ & $\mathrm{T}$ & $\mathrm{T}$ & $\mathrm{T}$ \\
\hline
\end{tabular}

The extract of polarity 4.3 of the plant Lactuca sativa L. var. longifolia has a bactericidal character from the concentration $(190 \mathrm{mg} / \mathrm{mL})$, whereas the extract of polarity 8.7 of the plant Lactuca sativa L.var. crispa demonstrated a bacteriostatic effect at a concentration of $(250 \mathrm{mg} / \mathrm{mL})$. In general, Lactuca sativa L. has a remarkable inhibitory effect at high concentration, this can be explained by the low concentration of the active molecule or molecules that can exert a synergetic effect on these above-mentioned strains.
3.5.Assessment of in-vitro anti-inflammatory activity / Inhibition of albumin denaturation

Anti-inflammatory activity of the Lactuca sativa L. extracts was evaluated against heatinduced denaturation of bovine serum albumin. The outcomes of these experiments are summarized in Table 9, within, we observed an increase of the absorbance in the test samples with respect to the negative control which indicated the stabilization of the protein.

All extracts of Lactuca species were able to inhibit protein denaturation in a concentrationdependent manner and exhibited appreciable inhibition of heat-induced protein denaturation ranged from $\left(25.47 \pm 1.47^{\mathrm{EF}} \%\right)$ to $\left(80.36 \pm 3.6^{\mathrm{A}}\right.$ $\%)$ for Lactuca sativa L. var. crispa , $\left(20.02 \pm 0.16^{\mathrm{FGH}} \%\right.$ to $\left.66.59 \pm 2.97^{\mathrm{B}} \%\right)$ for 
Lactuca sativa L. var. capitata $\mathrm{L}$ nidus tenerrima, $\left(15.91 \pm 2.32^{\mathrm{HI}} \%\right)$ to $\left(50.12 \pm 1.74^{\mathrm{CD}}\right.$ $\%)$ for Lactuca sativa L. var. capitata $\mathrm{L}$ nidus jaggeri and $\left(11.75 \pm 2.25^{\mathrm{I}} \%\right)$ to $\left(44.77 \pm 3.38^{\mathrm{D}} \%\right)$ for Lactuca sativa L. var. longifolia.
From the result of the present study, at the solvent polarity 5.8, Lactuca sativa L. var. crispa showed $(80.8 \%)$ as the maximum inhibitory activity on protein denaturation at 1 $\mathrm{mg} / \mathrm{ml}$ (Table 9).

Table 9. Percentage inhibition of the bovine serum albumin denaturation of the extracts of Lactuca sativa $\mathrm{L}$. for each solvent, values lacking a common letter are significantly different at $\mathrm{p}<0.05$ (Tukey's HSD test)

\begin{tabular}{|c|c|c|c|c|}
\hline & \multicolumn{2}{|c|}{ Green varieties } & \multicolumn{2}{c|}{ Red varieties } \\
\hline $\begin{array}{c}\text { SOLVENT } \\
\text { POLARITY }\end{array}$ & $\begin{array}{c}\text { Lactuca sativa } \\
\text { L. var. } \\
\text { longifolia }\end{array}$ & $\begin{array}{c}\text { Lactuca sativa } \mathrm{L} . \\
\text { var. } \text { capitata } \mathrm{L} \\
\text { nidus } \text { jaggeri }\end{array}$ & $\begin{array}{c}\text { Lactuca sativa } \mathrm{L} . \\
\text { var. } \text { capitata } \mathrm{L} \\
\text { nidus tenerima }\end{array}$ & $\begin{array}{c}\text { Lactuca } \\
\text { sativa } \mathrm{L} \text {. var. } \\
\text { crispa }\end{array}$ \\
\hline 4.3 & $11.75 \pm 2.25^{\mathrm{I}}$ & $15.91 \pm 2.32^{\mathrm{HI}}$ & $20.02 \pm 0.16^{\mathrm{FGH}}$ & $25.47 \pm 1.47^{\mathrm{EF}}$ \\
\hline 5.8 & $44.77 \pm 3.38^{\mathrm{D}}$ & $50.12 \pm 1.74^{\mathrm{CD}}$ & $66.59 \pm 2.97^{\mathrm{B}}$ & $80.36 \pm 3.6^{\mathrm{A}}$ \\
\hline 7.3 & $11.39 \pm 2.51^{\mathrm{I}}$ & $43.79 \pm 3.59^{\mathrm{D}}$ & $56.14 \pm 1.79^{\mathrm{C}}$ & $70.02 \pm 1.74^{\mathrm{B}}$ \\
\hline 8.7 & $24.14 \pm 1.11^{\mathrm{EFG}}$ & $29.23 \pm 2.03^{\mathrm{E}}$ & $56.24 \pm 1.80^{\mathrm{C}}$ & $65.3 \pm 0.84^{\mathrm{B}}$ \\
\hline 10.2 & $22.59 \pm 3.00^{\mathrm{EFGH}}$ & $17.49 \pm 3.82^{\mathrm{GHI}}$ & $50.55 \pm 5.14^{\mathrm{CD}}$ & $56.10 \pm 1.84^{\mathrm{C}}$ \\
\hline
\end{tabular}

\subsection{Data analysis}

The hierarchical ascending classification of the twenty extracts from the four varieties of Lactuca sativa $\mathrm{L}$ as well as their designations are depicted in the Table 1, by the dissimilarity of the Euclidian distance based on Ward's Aggregation Algorithm, entailed the distribution of these extracts into three main group as depicted in Figure 2:

The first group includes the ethanolic extracts of polarity 4.3 of the four varieties $\left(\mathrm{EX}_{15}, \mathrm{EX}_{25}, \mathrm{EX}_{35}\right.$ and $\left.\mathrm{EX}_{45}\right)$, the aqueous as well as the hydroalcolic extracts of polarity 10.2 and $5.8\left(\mathrm{EX}_{11}, \mathrm{EX}_{21}, \mathrm{EX}_{14}\right.$ and $\left.\mathrm{EX}_{24}\right)$ of the two green varieties.

The second group has hydroalcolic extracts $\left(\mathrm{EX}_{12}\right.$ and $\left.\mathrm{EX}_{22}\right)$ of polarity 8.7 for green varieties and polarity extracts $7.3\left(\mathrm{EX}_{33}\right.$ and $\left.\mathrm{EX}_{43}\right)$ of red varieties as well.

Finally, the third group contains the extracts of polarity $7.3\left(\mathrm{EX}_{13}\right.$ and $\left.\mathrm{EX}_{23}\right)$ of the two green varieties, along with the extracts $\left(\mathrm{EX}_{34}, \mathrm{EX}_{41}\right.$ and $\mathrm{EX}_{44}$ ) of polarity 5.8 and 10.2 belonging to the red varieties.

The heat map depicted in Figure 2, demonstrate that the polarity of the solvent and the type of lettuce cultivars influenced strictly the character of each extract. Indeed, the extract
$\mathrm{EX}_{44}$ of polarity 5.8 and which belongs to the variety Lactuca sativa L. var. crispa encompass both the antioxidant, antibacterial and antiinflammatory character due to its high content of polyphenol and flavonoids.

More particularly, statistical analysis by heat map technique shows that the extracts of the two red varieties as well as the $\mathrm{EX}_{24}$ extract tend to reduce ferric iron to ferrous iron, whereas, the green varieties have only low activity.

Furthermore, $\mathrm{EX}_{33}, \mathrm{EX}_{34}, \mathrm{EX}_{43}$ and $\mathrm{EX}_{44}$ have strong activity as regards of the inhibition of hydroxyl and DPPH radicals, while the extracts $\mathrm{EX}_{42}, \mathrm{EX}_{32}, \mathrm{EX}_{22}, \mathrm{EX}_{23}, \mathrm{EX}_{24}$ exhibited moderate activity.

In terms of antimicrobial activity, Staphylococcus aureus would be sensitive to both extracts $\mathrm{EX}_{12}(\mathrm{MIC}=1 \mathrm{~g} / \mathrm{L})$ and $\mathrm{EX}_{25}$ $(\mathrm{MIC}=1.5 \mathrm{~g} / \mathrm{L})$, while extracts $\mathrm{EX}_{24}, \mathrm{EX}_{44}$ and $\mathrm{EX}_{45}$ exhibited a less activity. On the other hand, the bacterium Pseudomonas aerugiosa tolerates all the extracts except the $\mathrm{EX}_{44}$ extract which exhibited an inhibition of it at a concentration of $1 \mathrm{~g} / \mathrm{L}$.

The anti-inflammatory activity tested in vitro showed that the hydro-alcoholic extracts of polarity 8.7 and 7.3 of the green varieties and the hydro-alcoholic extracts of the red varieties 
except the ethanolic extracts of polarity 4.3 possess a notable anti-inflammatory activity. The results of the PCA analysis are given as a two-dimensional correlation bi-plot and are depicted in Figure 3, the five extracts for each of the four varieties (i.e., 20 extracts) were studied, the results are presented in Table 1. The correlation matrix among the total extractions is summarized in Figure 3, thus capturing (75.02 $\%)$ of the total data variability.

Pearson's correlation analysis was performed to assess the correlations between matrix on plant extracts based on the antioxidant, antibacterial and anti-inflammatory activities and the content of polyphenols and flavonoids, the results showed significant positive correlations were found between

\begin{tabular}{|c|c|c|c|c|c|c|c|c|}
\hline & 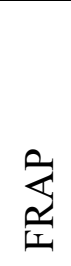 & $\frac{\vec{T}}{\vec{a}}$ & $\begin{array}{l}\text { } \\
\text { I } \\
\end{array}$ & 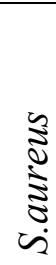 & $\begin{array}{c}0 \\
5 \\
0 \\
.5 \\
0 \\
\Xi \\
0 \\
0 \\
0 \\
2\end{array}$ & $\underset{4}{\ll}$ & ن & ن \\
\hline $\mathrm{EX}_{11}$ & 0 & 0 & 0 & 0 & 0 & 0 & 0 & 0 \\
\hline $\mathrm{EX}_{12}$ & 0 & 0 & 0 & 0 & 0 & 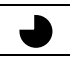 & 0 & 0 \\
\hline $\mathrm{EX}_{13}$ & 0 & 0 & 0 & 0 & 0 & (1) & 0 & 0 \\
\hline $\mathrm{EX}_{14}$ & 0 & 0 & 0 & 0 & 0 & 0 & 0 & 0 \\
\hline $\mathrm{EX}_{15}$ & 0 & 0 & 0 & 0 & 0 & 0 & 0 & 0 \\
\hline $\mathrm{EX}_{21}$ & 0 & 0 & 0 & 0 & 0 & 0 & 0 & 0 \\
\hline $\mathrm{EX}_{22}$ & 0 & 0 & 0 & 0 & 0 & 0 & 0 & 0 \\
\hline $\mathrm{EX}_{23}$ & 0 & 0 & 0 & 0 & 0 & 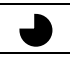 & 0 & 0 \\
\hline $\mathrm{EX}_{24}$ & 0 & 0 & 0 & 0 & 0 & 0 & 0 & 0 \\
\hline $\mathrm{EX}_{25}$ & 0 & 0 & O & 0 & 0 & 0 & 0 & 0 \\
\hline $\mathrm{EX}_{31}$ & 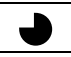 & 0 & 0 & 0 & 0 & 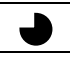 & (1) & $D$ \\
\hline $\mathrm{EX}_{32}$ & $D$ & 0 & 0 & 0 & 0 & $\partial$ & (1) & $D$ \\
\hline $\mathrm{EX}_{33}$ & 4 & 0 & 0 & 0 & 0 & & 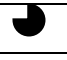 & \\
\hline $\mathrm{EX}_{34}$ & 4 & $D$ & 0 & 0 & 0 & 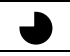 & 0 & $D$ \\
\hline $\mathrm{EX}_{35}$ & $\boldsymbol{D}$ & 0 & 0 & 0 & 0 & 0 & 0 & 0 \\
\hline $\mathrm{EX}_{41}$ & 0 & 0 & 0 & 0 & 0 & $\boldsymbol{J}$ & 0 & 0 \\
\hline $\mathrm{EX}_{42}$ & 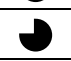 & 0 & 0 & 0 & 0 & & 0 & \\
\hline $\mathrm{EX}_{43}$ & 0 & 0 & 0 & 0 & 0 & 0 & 0 & 0 \\
\hline $\mathrm{EX}_{44}$ & 0 & $D$ & 0 & 0 & 0 & 0 & 0 & 0 \\
\hline $\mathrm{EX}_{45}$ & 0 & 0 & 0 & 0 & $\bigcirc$ & 0 & 0 & 0 \\
\hline
\end{tabular}

Figure 2. Heat map showing classification of 20 Lactuca sativa L. extracts activities. FRAP: Ferricreducing antioxidant power, DPPH: Antioxidant activity on DPPH free radical, $\mathrm{H}_{2} \mathrm{O}_{2}$ : Antioxidant activity on hydrogen peroxide, C.F: Content of flavonoid, C.P: Content of polyphenol, S.aureus: Antibacterial activity against staphylococcus aureus, P. aeruginosa: Antibacterial activity against Pseudomonas aeruginosa, AA: Anti-inflammatory activity content of polyphenol and flavonoids, antioxidant activities and anti-inflammatory activity with Pearson's correlation coefficients of $(0.810,0.824$ and 0.660$)$, respectively for FRAP, DPPH and $\mathrm{H}_{2} \mathrm{O}_{2}$ as well as a correlation coefficient of 0.787 with flavonoid content.

The flavonoid contents showed also a higher correlation versus antioxidant activities FRAP (0.830), DPPH (0.754) and $\mathrm{H}_{2} \mathrm{O}_{2}(0.729)$.

The antioxidant activity by $\mathrm{H}_{2} \mathrm{O}_{2}$ test showed similarly a positive correlation with DPPH test (0.822) and FRAP test (0.692)

In addition, DPPH test and FRAP test showed also a positive correlation between them (0.727).
$\mathrm{O}$ : Very low activity
: Low activity
: Medium activity
: High activity
: Very high activity 
Table 10 recapitulates the coefficient correlations (R) obtained between biological activities and Total phenols as well as flavonoids contents, within, we evaluated antiinflammatory activities and observed that antiinflammatory activity presented a positive correlation between antioxidant activities FRAP (0.780), DPPH (0.824), $\quad \mathrm{H}_{2} \mathrm{O}_{2} \quad(0.837)$, polyphenol content $(0.790)$ and flavonoid content (0.821), however, the antibacterial activity of pseudomonas aeruginosa presented a low correlation with the content of polyphenol (0.161), while the antibacterial activity of staphylococcus aureus exhibited a negative correlation.

Lactuca sativa L. var. crispa extract $\mathrm{EX}_{44}$ of polarity 5.8 showed the higher $\mathrm{F} 1$ and $\mathrm{F} 2$ factors respectively 4.171 and 3.223. PCA analysis confirmed that this extract presents antioxidant, anti-inflammatory and antibacterial properties since they are positively correlated with each other. This implies, solvent polarity influenced the polyphenols and flavonoids content of the extracts which in turn influenced the antioxidant, antibacterial and anti-inflammatory activities.

Table 10. Pearson's correlation coefficients of antioxidant, antibacterial((S.a: Staphylococcus aureus)(P.s: Pseudomonas aeruginisa)) and anti-inflammatory (AA) activities capacities, total polyphenol content $(\mathrm{CP})$ and total flavonoid content $(\mathrm{CF})$.

\begin{tabular}{|c|c|c|c|c|c|c|c|c|}
\hline Parameters & $\underset{\Sigma}{\mathbb{2}} a$ & $\widehat{\vec{\Delta}}$ & 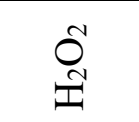 & $\sum_{\leq c}^{0}$ & $\sum_{j}^{n}$ & $\mathbb{Z}$ & 岂 & ช \\
\hline FRAP & 1 & & & & & & & \\
\hline DPPH & 0.727 & 1 & & & & & & \\
\hline $\mathrm{H}_{2} \mathrm{O}_{2}$ & 0.692 & 0.822 & 1 & & & & & \\
\hline 1/MIC S.aureus & -0.099 & -0.269 & -0.198 & 1 & & & & \\
\hline 1/MIC P.aeruginosa & 0.400 & 0.310 & 0.371 & 0.264 & 1 & & & \\
\hline Anti-inflammatory & 0.780 & 0.824 & 0.837 & -0.145 & 0.400 & 1 & & \\
\hline $\mathrm{CF}$ & 0.830 & 0.754 & 0.729 & -0.118 & 0.426 & 0.821 & 1 & \\
\hline $\mathrm{CP}$ & 0.810 & 0.824 & 0.660 & -0.209 & 0.161 & 0.790 & 0.787 & 1 \\
\hline
\end{tabular}

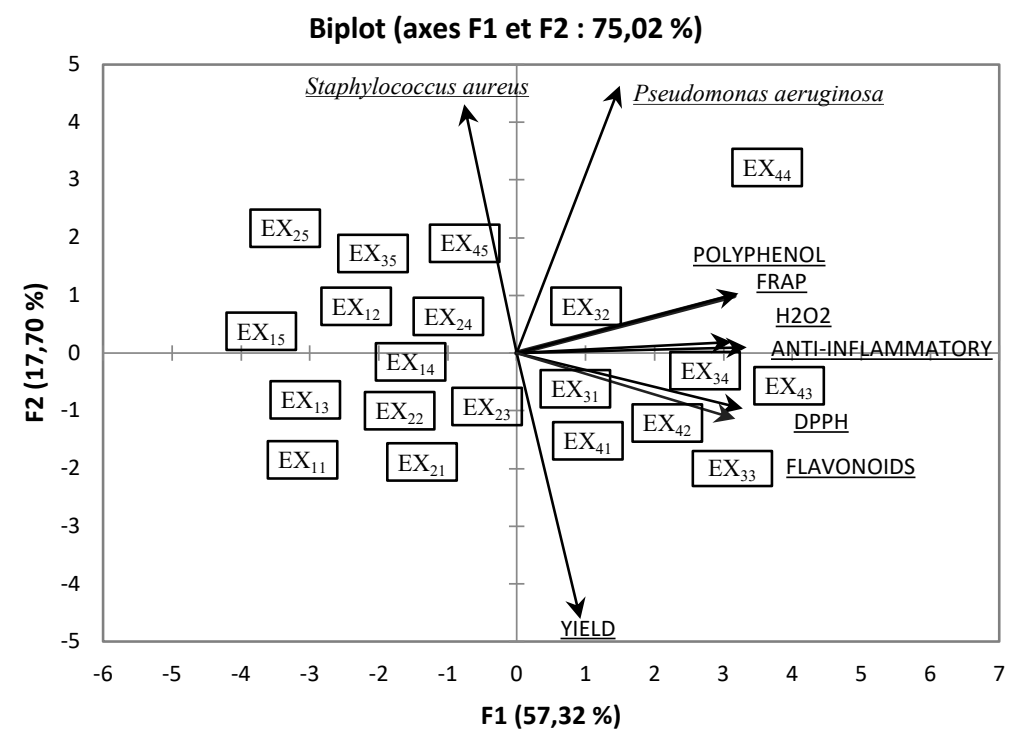

Figure 3. Bi-plot representation on the factor-plane (PC1-PC2) showing vector distribution of phytochemical contents, antioxidant and anti-bacterial activities within score plot of 20 extracts of Lactuca sativa $\mathrm{L}$. varieties 


\subsection{In-vivo antioxidant activity}

In vitro experiments may be a useful indicator of a potential in vivo bioactivity, the method was conducted to evaluate the antioxidant capacity of plasma against the DPPH radicals, and the activity was performed more particularly to assess in-vivo antioxidant activity of the extract $\mathrm{EX}_{44}$, our results are depicted in Table 11 and showed that the administration of $\mathrm{EX}_{44}$ at $4 \mathrm{~g} / \mathrm{kg}$ body weight dose, exhibited a maximum absorption at the wavelength of $517 \mathrm{~nm}$ as opposed to the negative control. Moreover, no significant difference using Tukey's HSD test was observed between ascorbic acid ( $\left.\mathrm{IP}=29.94 \% \pm 1.00^{\mathrm{A}} \%\right)$ and the $\mathrm{EX}_{44}$ extract $\left(\mathrm{IP}=29.12 \% \pm 3.00^{\mathrm{A}} \%\right)$.

Table 11. Plasma absorbance of rats treated by extract $\mathrm{EX}_{44}$ and ascorbic acid as a positive control, compared with a negative control, Different letters in superscript indicate significant difference at $\mathrm{p}<$ 0.05 (Means and SD as error bars, Tukey's HSD test).

\begin{tabular}{|c|c|c|}
\hline Treatment & Dose & Antioxidant activity of plasma (Means \pm SD) \\
\hline Negative Control & $1 \mathrm{~mL} / \mathrm{kg}$ & $22.09 \% \pm 2.00^{\mathrm{B}}$ \\
\hline Ascorbic acid & $10 \mathrm{mg} / \mathrm{kg}$ & $29.94 \% \pm 1.00^{\mathrm{A}}$ \\
\hline Extract $\mathrm{EX}_{44}$ & $4 \mathrm{~g} / \mathrm{kg}$ & $29.12 \% \pm 3.00^{\mathrm{A}}$ \\
\hline
\end{tabular}

\subsection{In-vivo anti-inflammatory Activity}

Formalin administrated to the paw of rats causes inflammatory pain by inducing capillary permeability and liberating endogenous substances which excite the pain nerve ending thus producing swelling of the paw (Viswanatha, et al., 2011). In this test, all the doses $(0.8,2$ and $4 \mathrm{~g} / \mathrm{kg}$ body weight) of the extract $\mathrm{EX}_{44}$ have shown significant inhibition of formalin - induced paw edema as compared to negative controls Table 12. On the other hand, the positive control carried out with dexamethasone, showed no significant difference compared to the batch treated by this extract at the doses of 2 and $4 \mathrm{~g} / \mathrm{kg}$ body weight, these results supported the results recently reported by (Gyawali et al., 2020).

Table 12. Kinetics of anti-inflammatory activity of the $\mathrm{EX}_{44}$ extract and Dexamethasone compared to a negative control, Different letters in superscript indicate significant difference at $\mathrm{p}<0.05$ (Means and

SD as error bars, Tukey's HSD test.

\begin{tabular}{|c|c|c|c|c|c|}
\hline Treatment & Dose & \multicolumn{4}{|c|}{ Development of volume paw $(\mathrm{mL})($ Means \pm SD) } \\
\hline & & Day 1 & Day 2 & Day 3 & Day 4 \\
\hline Negative Control & $1 \mathrm{~mL} / \mathrm{kg}$ & $1.59 \pm 0.06^{\mathrm{B}}$ & $1.68 \pm 0.08^{\mathrm{A}}$ & $1.36 \pm 0.06^{\mathrm{A}}$ & $1.15 \pm 0.06^{\mathrm{A}}$ \\
\hline Dexametasone & $10 \mathrm{mg} / \mathrm{kg}$ & $\begin{array}{c}1.08 \pm 0.04^{\mathrm{A}} \\
32.5 \%\end{array}$ & $\begin{array}{c}0.76 \pm 0.08^{\mathrm{C}} \\
49.4 \%\end{array}$ & $\begin{array}{c}0.70 \pm 0.20^{\mathrm{C}} \\
43.0 \%\end{array}$ & $\begin{array}{c}0.75 \pm 0.09^{\mathrm{C}} \\
39.2 \%\end{array}$ \\
\hline Extract EX $\mathbf{X}_{44}$ & $0,8 \mathrm{~g} / \mathrm{kg}$ & $\begin{array}{c}1.15 \pm 0.09^{\mathrm{C}} \\
29.4 \%\end{array}$ & $\begin{array}{c}1.01 \pm 0.07^{\mathrm{B}} \\
33.1 \%\end{array}$ & $\begin{array}{c}0.97 \pm 0.07^{\mathrm{B}} \\
26.0 \%\end{array}$ & $\begin{array}{c}0.90 \pm 0.05^{\mathrm{B}} \\
25.0 \%\end{array}$ \\
\hline
\end{tabular}




\begin{tabular}{|c|l|c|c|c|c|}
\hline & $2 \mathrm{~g} / \mathrm{kg}$ & $\begin{array}{c}1.03 \pm 0.06^{\mathrm{D}} \\
34.4 \%\end{array}$ & $\begin{array}{c}0.95 \pm 0.07^{\mathrm{B}} \\
43.8 \%\end{array}$ & $\begin{array}{c}0.77 \pm 0.05^{\mathrm{C}} \\
42.2 \%\end{array}$ & $\begin{array}{c}0.76 \pm 0.05^{\mathrm{C}} \\
35.0 \%\end{array}$ \\
\cline { 2 - 5 } & $4 \mathrm{~g} / \mathrm{kg}$ & $\begin{array}{c}1.05 \pm 0.03^{\mathrm{D}} \\
35.6 \%\end{array}$ & $\begin{array}{c}0.78 \pm 0.07^{\mathrm{C}} \\
50.0 \%\end{array}$ & $\begin{array}{c}0.79 \pm 0.05^{\mathrm{C}} \\
41.5 \%\end{array}$ & $\begin{array}{c}0.72 \pm 0.07^{\mathrm{C}} \\
36.7 \%\end{array}$ \\
\hline
\end{tabular}

\section{Conclusions}

Overall, this study reported comparative chemico-biological investigations of activities of 20 extracts from four varieties of Lactuca sativa L. More particularly, the polarity of the extraction solvent significantly affected extraction yield, polyphenol and flavonoid contents as well as antioxidant, antiinflammatory and antibacterial activities. Extraction yield growed with increasing polarity, hence the content of polyphenol and flavonoid among other metabolites showed an important value in solvent polarity comprised between 5.8 and 8.7. These results gave also proofs that consumption of red varieties of Lactuca species may bring more health beneficial effects than the green ones, indeed, content of flavonoids and polyphenolics compounds are more significant in the variety crispa. Mathematical statistics showed that polyphenols and flavonoids content were positively correlated with antioxidant and antiinflammatory activities. Furthermore, Principal Components Analysis showed that the extract $\mathrm{EX}_{44}$ of polarity 5.8 had the most important antioxidant and anti-inflammatory activities in vitro and in vivo as compared with the other extracts from the other varieties of Lactuca sativa species.

\section{References}

Ahangarpour, A., Oroojan, A. A., Radan, M. (2014). Effect of aqueous and hydroalcoholic extracts of lettuce (Lactuca sativa) seed on testosterone level and spermatogenesis in NMRI mice. Iranian Journal of Reproductive Medicine, 12(1), 65-72.

Al-Hejjaj, W. K. G., Intesar, T. N., Raghdan, Z. A., Saad, A. H. (2011). Anti-inflammatory activity of telmisartan in rat models of experimentally-induced chronic inflammation: comparative study with dexamethasone. Saudi Pharmaceutical Journal 19(1), 29-34.

Balouiri, M., Moulay, S., Saad, K. I. (2016). Methods for in vitro evaluating antimicrobial activity: A Review. Journal of Pharmaceutical Analysis, 6(2), 71-79.

Brindha, P., Arun, Kp. (2014). In vitro antiinflammatory, antioxidant and nephroprotective studies on leaves of Aegle marmelos and Ocimum sanctum. Asian journal of pharmaceutical and clinical research, 7(4), 121-129.

Chekroun, E., Benariba, A. N., Bechiri, H., Azzi, A., Djaziri, R. R. (2015). Antioxidant Activity and Phytochemical Screening of Two Cucurbitaceae: Citrullus colocynthis Fruits and Bryonia Dioica Roots. Asian Pacific Journal of Tropical Disease, 5(8), 632-37.

Darwish, A. G. G., Samy, M. N., Sugimoto, S., Matsunami, K., Otsuka, H. (2018).

Principal component and heat map analysis of the biological activities for some selected medicinal plants. Academia Journal of Medicinal Plants 6(6), 101-113. Edziri, H. L., Smach, M. A., Ammar, S., Mahjoub, M. A., Mighri, Z., Aouni, M., Mastouri, M. (2011). Antioxidant, antibacterial and antiviral effects of Lactuca sativa extracts. Industrial Crops and Products, 34(1), 1182-1185.

El Akrem, H., Manaf, A., Marielle, B., Moktar, H. (2007). The effects of solvents and extraction method on the phenolic contents and biological activities in vitro of Tunisian Quercus coccifera L. and Juniperus 
phoenicea L. fruit extracts. Food Chemistry, 105 (2007), 1126-1134.

Gan, Y. Z. and Azrina, A. (2016). Antioxidant properties of selected varieties of lettuce (Lactuca sativa L.) commercially available in Malaysia. International Food Research Journal, 23(6), 2357-2362.

Gyawali, R, Ghimire, A., Khatiwada, A., Niraula, P., Sharma, U., Thapa, R. (2020). Anti-inflammatory, Anxiolytic and Antioxidant Property of Lactuca sativa L and Formulation of Microspheres Loaded Sustained Release Anti-inflammatory Gel. Journal of Nepal Chemical Society, 41(1), 815.

Harsha, S. N., Anilakumar, K. R., (2013). Anxiolytic property of Lactuca sativa, effect on anxiety behaviour induced by novel food and height. Asian Pacific Journal of Tropical Medicine, 6(7), 532-536.

Harsha, S. N., Anilakumar, K. R., Mithila, M. V., (2013). Antioxidant properties of Lactuca sativa leaf extract involved in the protection of biomolecules. Biomedicine and Preventive Nutrition, 3(4), 367-73.

Liu, X., Ardo, S., Bunning, M., Parry, J., Zhou, K., Stushnoff, C., Stoniker, F., Yu, L., Kendall, P. (2007). Total Phenolic Content and DPPH Radical Scavenging Activity of Lettuce (Lactuca Sativa L.) Grown in Colorado. LWT Food Science and Technology, 40(3), 552-557.

López, A., Javier, G. A., Fenoll, J., Hellín, P., Flores, P. (2014). Chemical Composition and Antioxidant Capacity of Lettuce: Comparative Study of Regular-Sized (Romaine) and Baby-Sized (Little Gem and Mini Romaine) Types. Journal of Food Composition and Analysis, 33(1), 39-48.

Llorach, R., Martínez, S. A., Tomás, B. F.A., Gil, M.I., Ferreres, F. (2008). Characterisation of polyphenols and antioxidant properties of five lettuce varieties and escarole. Food Chemistry, 108(3), 1028-1038.

Pinto, E., Almeida, A. A., Aguiar, A. A., Ferreira, I. M. P. L. V. O. (2015). Comparison between the mineral profile and nitrate content of microgreens and mature lettuces. Journal of Food Composition and Analysis, 37(3), 38-43.

Pirvulescu, A., Sala, F. (2013). The Influence of Biocompatible Magnetic Fluids on The content of mineral elements in lettuce. Research Journal of Agricultural science, 45(1), 202-207.

Quy, D. D., Artik, E. A., Phuong, L. T.N, Lien, H. H., Felycia, E. S., Suryadi, I., Yi-Hsu, J. (2013). Effect of extraction solvent on total phenol content, total flavonoid content, and antioxidant activity of Limnophila aromatica. journal of food and drug analysis, 22(2014), 296-302.

Saikat, M., and Jun, Y. (2008). Principle Component Analysis and Partial Least Squares: Two Dimension Reduction Techniques for Regression in: CASUALTY ACTUARIAL SOCIETY, 2008 DISCUSSION PAPER PROGRAM Applying Multivariate Statistical Models. Québec City, Québec, Canada.

Saumya, S. M., Mahaboo, B. P. (2011). In vitro evaluation of free radical scavenging activities of panax ginseng and lagerstroemia speciosa: a comparative analysis. International Journal of Pharmacy and Pharmaceutical Sciences, 3(1), 1-5.

Smania, A., Smania, E. F. A., Franco, D. (2006). Derivatization does not influence antimicrobial and antifungal activities of applanoxidic acids and sterols from Ganoderma Spp. Z. Naturforsch. 61c, 31-34.

Snyder, L. R. (1974). Classification of the solvent propreties of common liquids. Journal of chromatography, 91, 223-230.

Soottawat, B., Wittayachai, L., Friedrich, B. (2004). Antioxidant activity of Maillard reaction products from a porcine plasma protein-sugar model system. Food Chemistry ,93 (2005), 189-196.

Soro, T. Y., Traore, F., Sakande, J. (2009). Analgesic activity of the aqueous extract from Ximenia Americana. Comptes rendus biologies, 332(4), 371-377.

Soro, T. Y., Zahoui, O. S., Nene-bi, A. S., Traore, F. (2016). Analgesic activity of the 
fractions of the aqueous extract of Ximenia Americana (Linné) (Olacaceae). International Journal of Pharmacology and Toxicology, 4(1), 1-6.

Viswanatha, GL., Akinapally, N., Shylaja, H., Nandakumar, K., Srinath, R., Janardhanan, S. (2011). Analgesic, anti-inflammatory and antiarthritic activity of newly synthesized bicyclothieno $1,2,3$ - triazines. Macedonian. Journal of Medical Sciences, 4(2),131-138.

Zekkori, B., Khallouki, F., Bentayeb, A., Fiorito, S., Preziusoc, F., Taddeo, V. A., Epifano, F., Genovese, S. (2018). A new phytochemical and anti-oxidant and antiinflammatory activities of different Lactuca sativa L. var. crispa extracts. Natural product communication, 13(9), 1139-1142. 